\title{
TAX ASPECTS OF DESTROYING AN ESTATE IN TENANCY BY THE ENTIRETIES \\ IN PENNSYLVANIA
}

\author{
Bernard V. Lentz $\dagger$
}

Factors Which Lead to Breaking Up of a Tenancy by the ENTIRETIES

Useful as it may be in many situations, the common law estate of tenancy by the entireties is normally exploited on too broad a front by those who do their own estate planning without professional assistance. As a result it often happens that the first job of the professional advisor is to break up the estate which the parties have formed and in that way create a situation which permits a certain freedom of maneuver in the development of a logical estate plan. ${ }^{1}$

This article assumes a case in which:

1. The husband and wife have a considerable estate, all of which is held in the joint names of husband and wife with right of survivorship.

2. The entire estate originated with the husband.

3. The estate is composed of:

Jointly owned real estate
Joint checking account
Joint savings account
United States Series "D" and "E" Bonds
Jointly owned stocks

$\$ 40,000.00$

$10,000.00$

$10,000.00$

$50,000.00$

$100,000.00$

Total

$\$ 210,000.00^{2}$

It is further assumed that the parties, if so advised by counsel, are prepared to break up the joint ownership with respect to any of

† B.S., Haverford College; LL.B., University of Pennsylvania; Member of the Pennsylvania Bar; Lecturer, New York Tax Institute, Pennsylvania Tax Institute, American Law Institute, Penn State Tax Institute.

1. See Mills, Tenancy by the Entireties-A Tax Booby-Trap?, 32 Mich. STate B.J., no. 5, p. 7 (1953), and summary thereof in Digest of Tax Articles 20 (Dec. 1953). H.R. 8300, 83d Cong., 2d Sess. \$2515 (1954) would solve most of the problems discussed herein if it ultimately becomes law. 
the classes of property which they hold. While there are many possible reasons for such a move, the principal ones would include:

1. A purpose to avoid a tax on the entire estate at the death of the wife following the death of the husband. Obviously in the case stated above, if the husband dies first the wife will become the absolute owner of the entire estate and when she thereafter dies, it will all be subject to estate and inheritance taxes. This particular problem can be solved by causing approximately one half of the estate to be returned to the individual ownership of the husband. $\mathrm{He}$ can then by his will set up a trust of such individually owned property for his wife, under which she would receive the income, plus a limited power of invasion of the principal, the principal remaining at her death to be passed on to children or other successors in interest. Under such a plan the wife, after the husband's death, would own one half of the estate outright and would be the life beneficiary of a trust with respect to the other half. Her estate would be taxed at her death under the estate and inheritance tax laws only on the one half which she owned outright. $^{8}$

2. A purpose to insure that the cost of the property for income tax purposes, after the death of the husband, will be equal to the value of the property as computed for estate tax purposes in the settlement of his estate, as contrasted with a lower actual cost of acquisition. ${ }^{4}$ This again would indicate that low cost property should be transferred back to the husband.

3. A purpose to divide the estate between separate ownership by the husband and separate ownership by the wife, in this way creating two small estates which will fall in the lower estate tax brackets regardless of whether husband or wife is the survivor. The accomplishment of this purpose obviously calls for transfer of some of the property, or an interest therein, to the wife, and the return of other property to the husband..$^{5}$

2. The illustration may seem extreme, but it is encountered in actual practice in substantially the form presented.

3. It is to be assumed that the limited power of appointment meets the restrictions specified in INT. REv. CODE $\S 811$ (f) (3) or (5) and, therefore, does not bring the trust property into the wife's gross estate.

4. INT. REv. CODE $\$ 113(\mathrm{a})(2)$ will govern the wife's cost on a sale if the property is left in tenancy by the entireties, i.e., if she takes her husband's original cost in computing gain. If wife receives the property from husband under his will, wife's cost is fair market value at date of husband's death. INT. REv. CODE $\$ 113(\mathrm{a})(5)$.

5. In the case stated, the wife has no separate estate. If she dies first, no part of the joint estate is "washed" through her federal estate tax exemption of $\$ 60,000$; and, unless husband remarries, he will get no marital deduction at his subsequent death. 
The object of this paper is to examine the tax consequences of the various transfers which may be called for from husband to wife, or vice versa, in order to accomplish the appropriate destruction of the tenancy by the entireties with respect to any of the classes of property owned by the parties.

\section{Tax Consequences of Retransfer of Property to Husband's INDIVIDUAL OWNERSHIP}

\section{The Real Estate Now Held as Tenants by the Entireties}

Federal Gift Tax Consequences of Retransfer to Husband:-It is elementary that when real estate is the subject of an estate by the entireties neither husband nor wife can destroy the estate without the agreement of the other. ${ }^{8}$

If the wife surrenders the rights which she acquired when the tenancy was created, she will have made a gift to the husband measured by exactly the same valuation factors which apply at the time such an estate is created. Specifically, the wife's gift will be equal to the sum of (a) the present value of her right to one half the income from the property during the joint lives of the parties, plus (b) the present value of her right to the entire property in the event she is the survivor. ${ }^{7}$ If the parties are of substantially the same age, the value of the interest retransferred to the husband upon destruction of the tenancy by entireties will be roughly equal to one half the value of the entire property. ${ }^{8}$

Since the transfer is from one spouse to the other, the gift will qualify for the marital deduction so that only one half of the gift actually made will be taxed. ${ }^{9}$ In the illustration given above, the total value of the real estate was $\$ 40,000$. If we assume that the wife's interest is worth $\$ 20,000$, then only one half of this, or $\$ 10,000$, will be regarded as a net gift because of the marital deduction. From exist:

6. While the statement in the text is generally true, two special exceptions do

(1) At divorce, each party gets one half. PA. Stat. ANN. tit. 68, $\S 501,503$ (Purdon 1931).

(2) If husband fails to comply with a support order, the property can be sold and wife receives (a) a part of the proceeds proportionate to her contribution to the property, and (b) enough to pay the support order. PA. STAr. ANN. tit. 48, \&137 (Purdon 1930). See Commonwealth ex rel. Greenawalt v. Greenawalt, $347 \mathrm{~Pa}$. 510, 32 A.2d 757 (1943).

7. U.S. Treas. Reg. $108, \S 86.19(\mathrm{~h})$ (1943) specifies these factors as measuring the value of the interest received by the wife when the entireties is created. There is no reason to use a different measure when the wife gives back such an interest.

8. This follows from the fact that both parties would have substantially equal chances of being the survivor.

9. INT. REv. CoDE $\$ 1004$ (a)(3) (A) provides for a marital deduction equal to one half the value of the gift. 
this net gift of $\$ 10,000$, the annual exclusion of $\$ 3,000$ will be subtracted and thereby further reduce the gift to $\$ 7,000 . .^{10}$ This balance, or $\$ 7,000$, can be absorbed by the wife's lifetime exemption of $\$ 30,000$ under the gift tax statute. ${ }^{11}$

Federal Estate Tax Consequences:-The property will be included in the gross estate of the husband after the transfer back to him, but this would have been true even if it were left in tenancy by the entireties. ${ }^{12}$ However, once the property is again owned individually by the husband, he is free to draw his will in such a way that the property will or will not qualify for the marital deduction at his death. $^{13}$ He has thereby gained a power of choice as to disposition which did not exist while the property was held in tenancy by the entireties.

Income Tax Consequences:-Assuming that the property is worth a great deal more than its original cost, it will, as a result of the retransfer to the husband, acquire a much higher basis, i.e., a basis equal to the value used in determining the husband's estate tax liability as contrasted with the actual cost of acquisition which would have continued in effect if the property had been left in, tenancy by the entireties. Accordingly, if the property is sold by the wife subsequent to the husband's death, a substantial saving in capital gains tax will have resulted from destruction of the tenancy by the entireties. ${ }^{14}$

Pennsylvania Inheritance Tax Consequences:-Whereas the property was exempt from inheritance tax while held as tenants by the entireties, it now becomes subject to that tax. But the magnitude of this tax is not of sufficient importance to dictate the development of an estate plan in the case stated above.

\section{The Joint Checking Account and the Joint Savings Account}

Gift Tax Consequences of Retransfer to Husband:-The law of Pennsylvania, unlike that of certain other states, ${ }^{15}$ recognizes that the estate in tenancy by the entireties may exist in all forms of personal property and is not confined to real property. ${ }^{16}$ Thus, it has been

10. The exclusion of $\$ 3,000$ is permitted by INr. Rev. Cone $\S 1003$ (b) (3).

11. INT. REv. CODE $\S 1004$ (a) (1).

12. INT. REF. CODE $\$ 811$ (e) (1).

13. INT. REv. Code $\$ 812$ (e) (1).

14. See note 4 sipra. If the property has a lower value at husband's death than it had when purchased and put into the entireties estate, the wife will not get a loss deduction which would have been available if the property were business or investment property and had been left in the tenancy by the entireties.

15. See Note, Estate by Entireties in Personal Property, 117 A.L.R. 915 (1938).

16. Madden v. Gosztonyi Savings and Trust Co., $331 \mathrm{~Pa}$ 476, 200 Atl. 624 (1938). 
held that regardless of whether a bank account is created in the names of "husband and wife, either to draw," or simply in the names of "husband or wife," an estate by the entireties is created, despite the fact that either party has the authority, as against the bank, to make withdrawals without the joinder of the other. ${ }^{17}$ But neither husband nor wife, acting alone, may, as against the other, withdraw the fund for purposes foreign to their common interests. ${ }^{18}$ If the wife does not agree to the husband's withdrawing the fund and depositing it in his own name, the estate by entireties continues to exist despite the form of deposit. On first impression this would suggest that if the wife consents to a retransfer of a joint bank account to the individual name of the husband, she is releasing a property interest in the account of which she could not be deprived without her consent. She might, therefore, be regarded as having made a "gift" within the meaning of the federal tax statute. ${ }^{19}$

Two regulations under the federal statute have close, if indirect, bearing on this set of facts: Subsection 4 of Regulation 108, Section 86.2, provides:

"If A creates a joint bank account for himself and B (or similar type of ownership where $A$ can regain the entire fund without $B$ 's consent) there is a gift to $B$ when $B$ draws upon the account for his own benefit, to the extent of the amount drawn." ${ }^{20}$

\section{Subsection 6 provides:}

"If a husband with his own funds purchases property and has the title thereto conveyed to himself and wife as tenants by the entirety, and under the law of the jurisdiction governing the rights of the tenants there is no right of severance by which either of the tenants, acting alone, can defeat the right of the survivor to the whole of the property, he consummates a gift of such property. . . ." 21

We thus have two regulations, one expressly dealing with joint bank accounts and the other expressly dealing with the creation of tenancy by the entireties by a husband who has the "title" to property "con-

17. Alcorn v. Alcorn, $364 \mathrm{~Pa} .375,72$ A.2d 96 (1950); Bostrom v. National Bank of McKeesport, $330 \mathrm{~Pa}$.65, 198 At1. 644 (1938); Berkowitz's Estate (No. 1), $344 \mathrm{~Pa}$. 481, 26 A.2d 296 (1942). 17 supra.

18. Berhalter v. Berhalter, $315 \mathrm{~Pa} .225,173$ Atl. 172 (1934), and cases cited note

19. See Madden v. Gosztonyi Savings and Trust Co., $331 \mathrm{~Pa} .476,200$ At1. 624 (1938). If she does consent and thereby makes the property that of the husband, she has obviously destroyed the entireties.

20. U.S. Treas. Reg. 108, §86.2, $\pi 4$ (1943).

21. U.S. Treas. Reg. 108, §86.2, $\llbracket 6$ (1943). 
veyed" to himself and his wife as tenants by the entireties. The use of the words "title" and "conveyed" in the second regulation suggests that it is directed primarily at cases in which real estate is involved; but it cannot be denied that the language is broad enough to reach the creation of a tenancy by the entireties in any class of property.

In determining the significance of subsection 4 of the regulation, dealing with bank accounts and subsection 6 , dealing with tenants by the entireties, we are forced to a close examination of the character of the interest of the husband and wife in a joint bank account under the law of Pennsylvania and to the underlying principles which govern application of the federal gift tax statute. Insofar as the law of Pennsylvania is concerned, it is clear that the husband would not succeed in converting the money to his own absolute individual ownership merely by writing a check and depositing the proceeds in a bank account opened in his name alone. ${ }^{22}$ It seems equally clear, however, that he can at any time, without accountability to his wife, draw out money contained in the joint account for a "family" purpose or any other purpose associated with the common interests of husband and wife, including support of children. ${ }^{23}$

In related areas of tax law it has been held that whenever a donor retains the power to apply property to the discharge of his legal obligations he is for tax purposes regarded as remaining the owner of the property. $^{24}$ In the sense that support of the common household and of children is a legal obligation of the husband, his creation of a joint bank account would appear to fall within this principle.

It therefore seems clear that in Pennsylvania a husband does not make a taxable gift when he creates a joint bank account from which either spouse can make withdrawals. In such a case the husband's continuing power to apply the fund at his own discretion to normal domestic and family objects leaves such a high degree of dominion and economic interest in him that the gift, in substance, is incomplete. Conversely, the wife would not be regarded as making a taxable gift

22. See notes 18 and 19 supra.

23. While the parties are living together, there is apparently a presumption that withdrawals are for joint use, and the wife would not be entitled to an accounting for expenditures made by the husband. See Marino v. Marino, 79 Pa. D. \& C. 597 (Phila. County, 1951); Wakefield v. Wakefield, 149 Pa. Super. 9, 25 A.2d 841 (1942). But if the parties are separated and there is evidence of fraudulent and hostile misappropriation by one spouse, an action for an accounting will lie. See Werle v. Werle, $332 \mathrm{~Pa} .49,1$ A.2d 244 (1938); Klein v. Klein, $71 \mathrm{~Pa} . \mathrm{D}$. \& C. 558 (Phila. County, 1950). Contra: Cullinan v. Cullinan, 72 Pa. D. \& C. 146 (Allegheny County, 1949). Kaufmann v. Kaufmann, 166 Pa. Super. 6, 13, 70 A.2d 481, 484 (1950), though involving a case of expenditure by the wife on her own support, strongly suggests that either party can make withdrawals for "domestic and family purposes."

24. Helvering v. Schweitzer and Helvering v. Stokes, 296 U.S. 551 (1935); Douglas v. Willcuts, 296 U.S. 1 (1935). See Montgomery, Federal TAXES-Estates, TRUSTS AND Girts 1017 (1952). 
back to her husband when she permits him to withdraw the joint account and restore the title to his own individual name. ${ }^{25}$

At this point it is appropriate to direct attention to the fact that under subsection 4 of the treasury regulation quoted above a husband would be regarded as making a gift to his wife if he permits her to make a withdrawal for her own benefit out of an account which he himself created.

In all cases thus far it has been assumed that either husband or wife can write checks on the fund because of the manner in which the account was opened. This power arises automatically if the deposit is in the names of husband or wife, and is conferred expressly by the opening of an account in the names of husband and wife "either to draw." ${ }^{26}$ If, however, a deposit is made simply in the name of "husband and wife" without more, both signatures are required to make a withdrawal. ${ }^{27}$ In such a case, the husband by opening the account has put the money outside his own control and would therefore appear to have made a gift to the wife within the federal tax law. If the wife later agreed to have the money restored to the husband's separate ownership, she too would apparently have made a taxable gift. $^{28}$

\section{The United States Series " $D$ " and "E" Bonds}

Federal Gift Tax Consequences:-In a number of states it has been held that because of the language of the federal regulation ${ }^{29}$ permitting either party, acting alone, to redeem the bonds, there can be no tenancy by the entireties in this type of property. ${ }^{30}$ But, although the Supreme Court of Pennsylvania has not directly passed on the

25. This would follow if the gift tax is to be construed consistently. While the wife, in agreeing that the fund shall become the separate property of the husband, is freeing the joint account of certain restrictions, the interest she thereby releases approaches zero because of the husband's power, acting alone, to spend the fund in performing his legal obligations. The conclusion reached here is to a considerable degree inconsistent with the analysis given to gifts of community property, i.e., the wife is regarded as the real owner of one half of community property despite her husband's power as manager to consume it on domestic objects. See 1 DE FUNIAK, Princtples GF CoMMunity PRoperty \$113 (1943); INT. Rev. Code \$1004(a) (3) (F) (i); Edward N. Mills, 12 T.C. 468 (1949), aff'd, 183 F.2d 32 (9th Cir. 1950). But community property is sui generis. It is not believed to offer persuasive analogies because of its peculiar historical and political background.

26. See cases cited notes 16,17 and 18 supra.

27. Milano v. Fayette Title \& Trust Co., 96 Pa. Super. 310 (1929).

28. These conclusions are implied by the language of U.S. Treas. Reg. 108, § 86.2, If 6 (1943), quoted in the text at note 21 supra.

29. 31 Code FED. REgS. $\$ 315.45$ (a) (Supp. 1952).

30. E.g., Estate of Charles H. Marsh, 125 Mont. 239, 234 P.2d 459 (1951). 
question, the weight of authority in Pennsylvania is in favor of the proposition that such bonds are held as tenants by the entireties when issued in the names of "husband or wife." 31 It thus appears that in Pennsylvania the relative rights of husband and wife in United States Savings Bonds are substantially identical with their relative rights in a joint bank account so that the same federal tax consequences should apply to both types of property.

This would mean that there would be no gift tax upon the wife's agreeing to a reissue of the bonds in the name of the husband alone, because the husband always retained the power to cash in the bonds and devote the proceeds to the discharge of his family and household obligations. ${ }^{32}$

\section{Jointly Orened Stocks}

Federal Gift Tax Consequences of Retransfer of the Stocks to the Individual Name of the Husband:-The normal registration of stock in cases similar to the one under consideration, would appear to be in the name of "husband and wife as joint tenants (or as tenants by the entireties) with right of survivorship." In fact, it is apparently contrary to established corporate practice to permit registration in the name of "husband or wife." 33 If we assume the usual form of registration in the names of husband and wife, both parties must join in a sale or other disposition of the stock. ${ }^{34}$

It logically follows that when the husband with his own funds buys stock which he causes to be placed in tenancy by the entireties, he makes a gift to the wife measured by the same factors which apply in the case of real estate. ${ }^{35}$ Likewise, if the wife later executes the necessary assignments to restore the title to the stock to the husband's name alone, she will be deemed to have made a gift back to the husband.

31. Alcorn v. Alcorn, $364 \mathrm{~Pa} .375,72$ A.2d 96 (1950), suggests by the strongest possible implication that a tenancy by the entireties exists in such bonds. To the same effect is Bowie Estate, 73 Pa. D. \& C. 264 (Mercer County 1950) (tenancy by entireties in proceeds of "D" and " $E$ " bonds).

32. See Mim. 5202, 1941-2 Cum. Burl. 241. If the bonds are delivered by the husband to the wife and placed in a deposit box to which she alone has access, strict logic would indicate that the husband has made a gift because of his complete loss of control. However, the above mimeograph would indicate that for gift tax purposes the gift is still not regarded as complete until the wife cashes the bonds. (1949).

33. Doris and Friedman, Corporate Secretary's Manual and Guide, 944

34. Magee v. Morton Building and Loan Ass'n, $103 \mathrm{~Pa}$. Super. 331, 158 At1. 647 (1930) (building and loan shares).

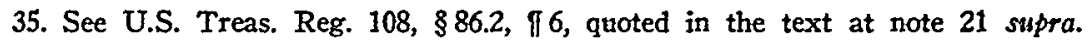


Tax Consequences of Division of Property Between Husband AND WIFE

\section{The Bank Accounts and United States Savings Bonds}

If any of the funds held in the joint bank account or any of the proceeds of the United States Savings Bonds are transferred to the wife's individual ownership, the husband will be deemed to have completed a taxable gift to his wife. ${ }^{36}$ Thus, if the bank accounts or the United States Savings Bonds are equally divided between husband and wife, the gift to the wife resulting from such division will equal one half of the amount which was formerly held in tenancy by the entireties. ${ }^{37}$

In this connection it may be observed that if the wife, acting alone, transfers the property into her own individual name, the tenancy by the entireties can be converted into tenancy in common, or of the property is included in the husband's gross taxable estate. ${ }^{38}$

As a result it will be preferable, in executing the program for destroying the tenancy by the entireties, to cause the bank accounts and United States Savings Bonds to be retransferred to the individual name of the husband. As noted, that can be done without gift tax consequences; yet the husband has, by reason of such action, reacquired a freedom of choice as to disposition which permits the development of a logical estate plan.

\section{The Real Estate and the Jointly Oroned Stocks}

Since the decision in Sullivan v. Commissioner, ${ }^{39}$ which involved real estate, a program whereby the entireties is converted into a tenancy in common has become fairly popular. If a husband and wife are of equal age, the value of the interests held by each after the conversion is the same as that held before the conversion. ${ }^{40}$ Accord-

36. This necessarily follows from the conclusion already reached to the effect that the mere creation of the joint bank account and the mere purchase of the bonds in two names does not involve a completed gift. See U.S. Treas. Reg. 108, § 86.2 II 4 quoted in the text at note 20 supra, and Mim. 5202, 1941-2 Cum. BuLl. 241.

37. The transfer of one half of the fund to the husband would not appear to offer an adequate consideration because, on the analysis already made, he was, for tax purposes, still the owner of the whole fund just before the parties agreed to divide it. An equal division at divorce under court order might result in a holding that no gift to the wife had occurred. See Alcorn v. Alcorn, $364 \mathrm{~Pa}$. 375, 72 A.2d 96 (1950); Harris v. Comm'r, 340 U.S. 106 (1950).

38. Estate of Harold W. Grant, 1 T.C. 731 (1943) ; Estate of Henry Wilson, 2 T.C. 1059 (1943).

39. 175 F.2d 657 (9th Cir. 1949), reversing 10 T.C. 961 (1948).

40. If the wife is the younger spouse, she will have made a gift back to the husband. Special Ruling Oct. 1, 1948, cited in MontgomerY, FEDERAL TAXEsEstates, TRUSTS AND Girts 982 (1952). 
ingly, while the nature of the interest held by each party has changed, there is, on the reasoning of the Sullivan case, no taxable gift.

The tax consequences of putting such a program into effect are:

1. Only one half the property is included in the husband's gross taxable estate upon his death, and because of the husband's absolute ownership of his undivided one half interest, he may dispose of it by his will. ${ }^{41}$

2. Upon the husband's death the cost of his one half interest will, for income tax purposes, be equal to its value at the date of his death, regardless of what was actually paid for the property during his lifetime. ${ }^{42}$

3. The correct manner of computing the cost of the wife's undivided one half interest in the tenancy in common is not yet clearly established. If the exchange of her interest as a tenant by the entireties for her new interest as a tenant in common is regarded as a taxable exchange giving rise to a gain, she could be held to have acquired a cost equal to the fair market value of her interest as tenant in common at the time the conversion was made. ${ }^{43}$ On the other hand, if this exchange of one type of interest in the property for another type of interest in the same property is regarded as a tax-free exchange, her cost for the undivided interest as tenant in common would be the same as the cost of her former interest in the entireties. Since she acquired that interest by gift from her husband, she would take over an appropriate portion of his original cost, and the figure so established would continue to represent the cost of her interest as tenant in common both before and after her husband's death. ${ }^{44}$ As to whether the conversion into tenancy in common does in fact produce a taxable transaction, a number of arguments can and have been made; ${ }^{45}$ but the point does not seem to have been presented in any

41. The undivided one half interest acquired by the wife is her separate property so that it is not includible in the husband's estate under INT. REv. CODE §811(e).

42. INT. Rev. Code $\$ 113(a)(5)$.

43. This is always "cost" after a taxable exchange, under INT. Rev. CoDE $\$ 113$ (a). It can be contended that the wife exchanges only a contingent right of survivorship in the whole property for a vested fee simple interest in an undivided one half interest. Both before and after the conversion she had an interest in one half the income during joint lives of husband and wife. See Mills, supra note 1.

44. Mills, supra note 1 . Her original cost would apparently be that proportion of the total acquisition price which the value of her original interest bore to the original value of the whole property. Direct rulings have not been disclosed by the writer's research.

45. Mills, supra note 1 at $15-6$, mentions possible nonrecognition under INT. REv. CODE $\S 112(\mathrm{~b})(2)$ or $112(\mathrm{n})$ (see particularly $\$ 112(\mathrm{n})(2)(\mathrm{A})$ ). He appears to assume the gain is realized. INT. REv. CoDE $\$ 112$ (b) (1) might also apply to prevent tax liability. 
decided case or ruling. A conservative plan would, therefore, allow for the possibility that the conversion might involve a taxable exchange with the result that if the value at the time of the proposed conversion is materially different from the original cost to the husband, the conversion should not be completed until the risk of realizing a capital gain or an unallowable loss has been measured against the estate tax advantages which are expected to accrue. ${ }^{48}$

While the conversion of an estate by the entireties into a tenancy in common appears to be most popular when real estate is involved, there is no compelling reason why the same action cannot be taken with respect to the corporate stocks held by husband and wife as tenants by the entireties. ${ }^{47}$ It will, however, be apparent that the ownership of such property as tenants in common is somewhat cumbersome in any event. For this reason, it is frequently preferable to have the husband and wife agree to a division of the total of the properties held in entireties on the basis that each will become the absolute owner of individual properties. In effectuating such a division, the husband in the case stated above could take back the real estate, which has a value of $\$ 40,000$ and become sole owner of that property, together with $\$ 30,000$ worth of the stocks. In exchange the wife could receive $\$ 70,000$ worth of stock in her own name. If we further assume that the bank accounts and United States Savings Bonds have all been returned to the individual ownership of the husband, there would then be no property held in the entireties. The husband would have a separate estate of $\$ 140,000$ consisting of :

Real Estate
Checking Account
Savings Account
United States Savings Bonds
Stocks

Total

$$
\begin{array}{r}
\$ 40,000.00 \\
10,000.00 \\
10,000.00 \\
50,000.00 \\
30,000.00
\end{array}
$$

$\$ 140,000.00$

and the wife would have an estate of $\$ 70,000$ consisting entirely of corporate stocks.

At this point, the husband is in a position to select exactly what property he wishes to qualify for the marital deduction and to determine

46. The loss, if any, would be unallowable because the exchange is between related taxpayers. INT. REv. CoDE $\$ 24(\mathrm{~b})(1)(\mathrm{A})$.

47. It was originally held that a husband and wife could not hold title to any property as tenants in common, but the rule was overturned by Blease v. Anderson, 241 Pa. 198, 88 Atl. 365 (1913), decided after enactment of the Married Women's Property Acts. 
what the total of the marital deduction should be at the time of his death. As the situation changes he can, merely by rewriting his will, readjust both the total amount and the composition of the marital deduction share thereunder.

The wife, on the other hand, now owns sufficient property in her own right so that even if she predeceases her husband she can by her will leave the property in such a way that it will ultimately pass practically free of estate tax. In the case under consideration, it could be provided by the wife's will that all of her property ( $\$ 70,000$ in stocks) should be held in trust for the husband during his lifetime so that he would receive the income and would have a limited, but nontaxable, power of invasion. At the time of the wife's death, the federal estate tax exemption of $\$ 60,000$ will preclude any substantial estate tax on her estate; and at the husband's subsequent death the property will be excluded from his gross estate because of the trust provision. Whether the foregoing division of the entireties estate will be undertaken in any actual case will obviously depend upon examination of the family situation and on the income tax consequences.

Insofar as income tax is concerned, it would appear that if husband and wife, owning a number of different stocks and real estate as tenants by the entireties agree that each spouse will become the absolute owner of certain separate pieces of property, a taxable exchange will probably result. ${ }^{48}$ If in the present case we assume that the real estate which now has a value of $\$ 40,000$ had a cost of only $\$ 20,000$, and that the wife in return for agreeing to its transfer back to the husband is to receive $\$ 40,000$ worth of stocks, which also had a cost of $\$ 20,000$, it is difficult to eliminate the possibility that each party to the exchange will be held to have realized a capital gain. Again, before action is taken, the risk of realizing a taxable gain or an unallowable loss must be compared with the estate tax advantages to be derived from the exchange.

\section{SUMMARY}

It will be seen that there are three basic procedures which can be followed for the purpose of destroying tenancy by the entireties:

1. In the case of bank accounts and United States Savings Bonds, the property can be returned to the ownership of the husband whose funds were originally involved in their creation or acquisition.

48. In effect each spouse has released an interest in one piece of property in exchange for a new interest in different property. In this sense, the case for realization of gain or loss is stronger than that presented by conversion of an entireties estate into a tenancy in common in the same property, but INT. REv. CODE $\S 112(\mathrm{~b})(2)$ would seem to apply where each class of stock is divided evenly. 
2. In the case of real estate and corporate securities, the tenancy by the entireties can be converted into tenancy in common, or

3. Separate pieces of property can be transferred to husband and wife respectively, in equal shares, so that after the transfer each holds, as his or her separate property, some of the properties that were formerly held by the entireties.

In the present state of the law any of such transfers can apparently be made without gift tax consequences. The resulting freedom of maneuver in estate planning is clear.

One caveat remains, viz., the possible realization of a capital gain, or an unallowable capital loss with consequent reduction in basis, whenever the parties agree to an exchange of their interests in property either for different interests in the same property or separate interests in separate property formerly held by the entireties. 